
\title{
BReserch S Suare \\ Vulnerability Status-Quo of the Underprivileged Communities in Mongla from Climate Change perspective
}

Masudul Haque Munna ( $\nabla$ masudul.munna@northsouth.edu )

North South University

Md. Sajadul Alam

North South University

Kaniz Fatema

Abdun Naqib Jimmy

North South University

\section{Research Article}

Keywords: Climate change, vulnerability, Hazard score, Community problem

Posted Date: February 17th, 2022

DOI: https://doi.org/10.21203/rs.3.rs-1341522/v1

License: (c) (1) This work is licensed under a Creative Commons Attribution 4.0 International License.

Read Full License 


\section{Abstract}

Climate-induced changes, such as extreme cyclones, devastating tidal surges, severe floods, river erosion, excessive rainfall, and overwhelming salinity intrusion, occur more frequently and unpredictably across Bangladesh. The frequency and intensity of these hazards are likely to increase due to climate change. This study considers the baseline situation of the grassroots people of Mongla Upazila \& community perception of climate change vulnerability and the local community-based adaptation strategies. Data were collected from respondents in Sundarban, Mithakahali, Chandpai, Sonailtola unions of Mongla Upazila, Bagerhat District, Bangladesh, an area subjected to frequent climate-related hazards. Many of the respondents within the target communities did not recognize the frequency and intensity of climate change. Most notably, although salinity was widely recognized as a significant problem for the community - agriculture, fisheries, biodiversity, trees, and plants, are all highly vulnerable - very few perceived an increased risk due to climate change. This suggests that communities do not predict perfectly an increased threat from these hazards and thus may not recognize the need to implement adaptation strategies further.

In this research, the highest hazard score is 12 , obtained by 100 families, illustrating that those families are in the most precarious position in terms of different climatic disasters the region faces. The table also elucidates that the hazard score of 12 is obtained by five families, illustrating that those families are in the most precarious position in terms of the region's different climatic disasters. The table also elucidates that the hazard score of forty-nine families is between 10 to 11.5 , more than $25 \%$ of the total respondents. Forty-two families lie between $8.5-9.5,43 \%$ of the total Respondent. The rest of the four respondents' score lies between $5.5-8,3.56 \%$ of the total respondents.

\section{Introduction}

Bangladesh is likely to be one of the most vulnerable countries in the world to disaster (P. Ahmed \& Biswas, 2012; Ali, 2012). From the historical period, the people of the deltaic region of this country are combating various natural calamities. Some are creeping, redundant, sudden, vivid, and devastating features among these disasters. These multifarious disasters occur for the geographic location of Bangladesh (Baten et al., 2018; Karim, 1995). Because of geographic location, abrupt weather changes, and riverine land, this country is vulnerable to natural disasters like floods, cyclones, drought, tornado, tidal surge, salinity, and many others. (Rahman et al., 2017). Furthermore, periodic riverbank erosion and flood cause millions of people's lives, homestead, and livelihood (MA Islam et al., 2017; MS Islam et al., 2015). Various anthropogenic hazards constantly threaten human life (Dewald, 2011; Dewan, 2015; ICSU, 2005). Among these, deforestation, pollution of the brick industry, use of harmful chemical fertilizer, shrimp virus has caused extensive damage to properties and human lives (M. A. R. Hossain \& Hasan, 2017; Jerin et al., 2017). These create devastating impacts on local people and the country's economy.

Bangladesh is also the most disaster-prone country for its geographic location, diversified weather conditions, and population density (Agrawala et al., 2003; Hasnat et al., 2018). Constantly, the disaster is 
causing death, including a threat to livelihood, environment, and economy (Sudmeier-rieux et al., 2006; Usman et al., 2013). Cyclone, flood, waterlogging, drought, riverbank erosion, and increasing saline intrusion are the major disasters that threaten human life and assets spontaneously (Masum, 2020). Furthermore, the intensity of disaster risk increases as the impact of climate change, impeding development. The districts of southwest Bangladesh are the most vulnerable for their social, economic, and environmental fragile condition (Md. Esraz-Ul-ZannatMaureen Fordham, Ahmed, Bayes, 2017). Bagerhat and its Mongla Upazila are highly risk-prone areas out of the districts. This sub-district is adversely affected by the cyclone and existing salinity throughout the year.

\subsection{Characteristics of Mongla}

Mongla Upazila (sub-district) consists of six unions is experiencing a shortage of livelihood and income options. In addition, there is severe water scarcity, social disparity, environmental degradation, disaster risk and vulnerability, poor women's rights condition, poor housing condition, social disharmony, lack of adequate health and educational facilities and poor governance. Due to climate change-induced vulnerabilities, the crucial challenges in the community people are; salinity intrusion over the agricultural land, temperature rise, heavy rainfall during the rainy season, acute shortage of cooking and drinking water, livelihoods options, and lower-income. Consequently, they cannot facilitate other needs of the households like children's education, getting health services, and feeding with nutritional foods. Salinity, shrimp virus, waterlogging and excessive rainfall adversely affect the lives and livelihood of the people of this area (I. Ahmed et al., 2019). On the other hand, creeping disaster salinity is causing unexpected damage to the agriculture and livestock sector.

Recent climatic change, especially severe hot weather, accompanied by frequent power outages, has made the lives of Mongla Upazila unbearable in the recent years as summer season (Profile \& Profile, 2016). The rivers, ponds, canals, open wetlands, and others reservoirs in the area and districts have virtually gone waterless this time (Davidson et al., 2001). During summer, the level of the groundwater goes deeper. About $30 \%$ of this Upazila appears to be affected by second-and third-degree salinity (Bhowmick et al., 2017). Due to river siltation and waterlogging at present, the percentage of salinity in the low land area is less the uprising of the sea level, causing a significant threat of submerging this area by the saline water (Sarwar, 2005). The massive shrimp farming practice of the people of this area is also responsible for increasing the level of salinity (Amoako Johnson et al., 2016; M. S. Hossain et al., 2013). About $74 \%$ of the populations in the coastal areas of Bangladesh have little or no access to safe drinking water (Benneyworth et al., 2016).

Despite many natural streams, ponds, and ample groundwater storage, the scarcity of potable water is acute in coastal areas (M. A. R. Hossain \& Hasan, 2017). Most of the time, the available river water is highly turbid and saline (Hasan et al., 2019). The lesser saline pond water can be used for many domestic purposes but is still unsafe for drinking. The region is also subject to the impacts of land-use changes since the 1980s, such as the conversion of agricultural land to saline shrimp ponds. These hydrogeological conditions and effects associated with inappropriate land use are becoming more 
aggravated because of climate change-induced sea-level rise and the reduction of upstream freshwater flow. The predicted sea-level rise in Bangladesh will induce salinity impacts in three critical natural water sources: surface water, groundwater, and soil (Abedin et al., 2019). Unlike other areas of Bangladesh, in the coastal regions of Khulna and Bagerhat, Mongla Upazila has several climate change-induced issues, including non-availability of drinking water, salinity, food insecurity, shrimp cultivation, increasing intensity and frequency of cyclones and tidal surge, river or dam erosion, lack of employment opportunity and increasing average tide heights.

The Mongla Upazila is a cyclone-prone area. From the entire disaster history of Mongla Upazila, data shows that almost every year, a low and high magnitude of cyclone strikes this area. The hurricane of 2007, 2009 caused devastating damage. This cyclone caused a tremendous negative impact on Sundarban, Chila, Mithakhali, and Suniltala unions. On the other hand, the whole area gets submerged during the rainy season as the depth of Rampal, Daudcanali, Echamati, and Belai Rivers decreases day by day (Khatun et al., 2017).

Moreover, as the drainage system is not well improved during the rainy season, the lowland areas of the Upazila get under the water. This water logging remains for two months. Furthermore, $95 \%$ of the indigenous houses are not cyclone-proof and submerged during floods. From the primary survey, various NGOs are working in Mongla focusing on micro-credit instead of climate change-induced issues.

Despite this, the development of water supply facilities in the entire Upazila is poor because of geological conditions that make installing deep and shallow tube wells difficult. On the other hand, most hand tube wells operate at a depth that offers water with high salt content. Most of the inhabitants became used to ponds and canal water for drinking and similar uses, making them often vulnerable to diseases from contaminated water and the adoption of poor hygienic and sanitation practices. The water crisis increases women's workload because they may have to walk long distances carrying water and sometimes their infant children. How this increased workload affects women's health is not tangible enough to calculate, but a significant amount of time, which could have been used productively, is lost in carrying water. The burden of health care for other family members is also the responsibility of women, and that too robs them of productive working time (Balakrishnan, 2005).

In a male-dominated society, women are always more vulnerable than men, and they constantly face crimination (Md. Asaduzzaman et al., 2015). However, the experience of Mongla tells that women have become more vulnerable due to climate change. Women are affected by social insecurity and financial problem, and sometimes they are frequently subjected to intimidation, gender-based violence, sexual harassment, and rape as the male members go elsewhere for earnings as the employment opportunity reduced due to climate change (Yasmin, 2020)

\section{Methods}

A baseline survey took place among the sample of the total number of existing families of Mongla Upazila. This baseline study is a design of qualitative and quantitative methods. The study is designed to 
get information from the families. Several households were interviewed through a four-page structured questionnaire during the data collection.

The aim of this baseline collection is twofold. The first is to assess and understand ongoing knowledge, attitudes, and practices of the project's target population, at the household and school level, concerning their needs and priorities in the disaster preparedness planning processes. This will provide baseline values for household knowledge and practices indicators and allow the activity team to fine-tune the targets and implementation strategies. This will be accomplished through examining community-level preparedness in four key areas, namely self-organization, ability to take action, knowledge, and awareness, and connectivity, aligning with the project's purpose of having the target communities, including schools, build their understanding of disaster risks, self-organize and take individual and collective action to establish a culture of preparedness and response, while reinforcing their networks and connectedness at the end of the project.

Therefore, the baseline data collection will comprise a household-level survey and a hazard score survey as well as an assessment of community and school disaster readiness, employing both qualitative and quantitative methods.

a) Household Survey: The community-level survey (multiple choice survey)

b) Hazard Score/Disaster Readiness: The assessment

(based on a checklist measuring community vulnerability) will survey the same households to quantify their exposure to disaster and ability

All data collected from the survey were analyzed using a statistical package (i.e., SPSS, Stata, or other statistical applications).

\subsection{Study Indicators and Data Sources}

The study's primary objective is to show the gap of livelihood security of the marginalized climatechange-affected communities. Therefore 100 data sets are collected from the study area's people living with their families.

\section{Results And Discussion}

\subsection{Respondents Characteristics}

Basic information has been collected to identify the socioeconomic characteristic of respondent households. Their current situations have been assessed through collecting the educational status, occupation, disability status. 
Data confirms that $80 \%$ of respondents are female, while the rest are male. The survey was a household survey, so most of the respondents were female.

Similar to the other regions of Bangladesh, this graph highlights that the main occupation of the study population was agriculture. About $30 \%$ of households were farmers by trade and another $16.66 \%$ resorted to fishing, mainly due to the availability of fish in the area. The casual laborers and beggars accounted for only $12.24 \%$, and farming accounted for $2.55 \%$ of the population.

Table 1: Disability Status of Household

\begin{tabular}{|l|l|}
\hline Disability Status & Percentage \\
\hline No Disabled & $97 \%$ \\
\hline Physically Disabled (Temporary) & $2 \%$ \\
\hline Physically Disabled (Permanent) & $1 \%$ \\
\hline Mentally Disabled & $0 \%$ \\
\hline
\end{tabular}

This study also explores the disability status of the respondents. Almost $97 \%$ of respondents are living without any disabilities. However, only $2 \%$ and $1 \%$ of respondents have temporary and permanent physical disabilities, respectively.

\subsection{Vulnerability Assessment of the Selected Areas}

Living in a highly disaster-prone area coupled with poverty and lack of awareness, only $48.45 \%$ of cases less than $20 \%$ of members need assistance during a disaster. In $20.48 \%$ of cases, more than $50 \%$ of household members need less help during a disaster.

Mongla is a high disaster-prone area with a significant percentage of land under risk. Survey findings show that about $71 \%$ of the site is low land while about $29 \%$ is near the riverside. This information highlights the amount of land under extreme threat to disaster.

The natural disasters in the study area have had severe impacts at the individual household level. So it's a must to know about climate change and its impact on their community. But, as the education level and their perception level are very poor; so they are not well off the upcoming effects of climate change. However, about $85.60 \%$ of respondents answered that temperatures became more unpredictable than before, and $11.69 \%$ replied that the precipitation cycle is tempered. As a result, rains are beginning later. 
According to the survey, the household condition of the project respondents is hazardous. Explains that about $39 \%$ of all the households are made up of bamboo/mud/jute stick/leave the wall, thatched/bamboo roof, and mud floor. Moreover, about $52 \%$ of households are made from brick plinth, and $\mathrm{mud} / \mathrm{wood} / \mathrm{bamboo}$ wall.

\begin{tabular}{|c|c|}
\hline Status on Climate Change Knowledge on Threats & Respondents \\
\hline Zero-Knowledge about Climate change and impact & 276 \\
\hline Aware of Climate Change & 197 \\
\hline Basic Knowledge about Climate Change & 27 \\
\hline
\end{tabular}

\section{Table 2: Status on Climate Change Knowledge on Threats}

The data represents that more than half of the respondents don't know about climate change and its impact. At the same time, about $40 \%$ of people have a concept about climate but not its impact.

The consumption of water is many, and its requirements vary both in quantity and quality. Conventionally, the study has analyzed the critical domestic uses of water like drinking, cooking, washing, and cleaning. Generally, the primary reported drinking and cooking water sources are almost similar and identified as $\mathrm{PSF} / \mathrm{RWHS}$ / and ring well. It is also consistent with the primary sources of drinking and cooking water of the surveyed population in general. The data shows that about $58 \%$ of people use PSF pipe water for drinking, while $35 \%$ and $9 \%$ use pond water (using ring well) and rainwater harvesting systems, respectively.

Analysis of the data denoted the income of the respondents is dependent on farming. Data confirms around $83 \%$ of the income is generated from subsistence farming. A significant share of the subsistence farming has to share with family to feed $-11.46 \%$ of the income generated from subsistence farming with selling some marketable goods in the market.

As the income of the respondents is highly farming dependent, to cultivate crops, water is essential. The water source is diminishing and creating a challenge for the farmers. $90 \%$ of pond water is used to grow crops, only $9 \%$ of the river water is used in crops cultivation.

The southwest coastal region of Bangladesh is highly disaster-prone, and Mongla Upazila of Bagerhat district is also a hazardous area. The above figure of this chapter explains the risk status this area is in. 
Table 3: Natural Disasters Face in Last One Year

\begin{tabular}{ll}
\hline Type of Disaster & Percentage of occurring \\
\hline Earthquake & $28 \%$ \\
River Erosion & $0 \%$ \\
\hline Heat Wave & $13.5 \%$ \\
\hline Cold Wave & $7 \%$ \\
\hline Drought & $9.5 \%$ \\
\hline Flood & $0.5 \%$ \\
\hline Heavy Rainfall & $14.5 \%$ \\
\hline Tidal Surge & $18 \%$ \\
\hline Cyclone & $8 \%$ \\
\hline Other & $1 \%$ \\
\hline
\end{tabular}

According to the first indicator of the project objective, the project interventions will reduce the Risk and vulnerability score of the beneficiaries' families who are vulnerable to climate

Change-induced disaster. To know the potential risk, the respondent's families were asked which natural disasters occurred in the last years.

This was multiple response questions, and among all respondents, $28 \%$ mentioned earthquake

That entire county faced several times in the last year. $18 \%$ mentioned tidal surge they face at

At least once a month because of low-lying land and tide. $13.5 \%$ of the respondent family mentioned heatwave and $14.5 \%$ mentioned heavy rainfall.

Around $39 \%$ of respondents claimed that the recent natural disaster that caused loss was cyclone KOMEN. $21 \%$ of respondents claimed tidal surge as a recently faced disaster, as they have to face it once in a month $\& 9 \%$ of respondents declared drought as a recently faced disaster.

Mongla Upazila is vulnerable to natural disasters like cyclones, tidal surges, and salinity. To know the community's perception on reducing disaster impact, they were asked which initiative should be taken to 
minimize the effects of the disaster. Around 58\% mentioned improving the infrastructure like road, cyclone shelter, bridge, etc. $57 \%$ said to improve the housing material and $29 \%$ respondents told that community needs more effective disaster response plan.

About $59 \%$ of respondents perceived that the days are becoming warmers and the number of warm days is increasing. Around $53 \%$ of respondents mentioned the rainfall in the concerning area is decreasing in frequency. Moreover, the period and timing of rain is becoming more unpredictable.

Table 4: Status of hazard score

\begin{tabular}{ll}
\hline Score & No. of families \\
\hline 5.5 & 0 \\
6.5 & 0 \\
\hline 7 & 0 \\
\hline 7.5 & 1 \\
\hline 8 & 3 \\
\hline 8.5 & 12 \\
\hline 9 & 12 \\
\hline 9.5 & 18 \\
\hline 10 & 24 \\
\hline 10.5 & 10 \\
\hline 11 & 11 \\
\hline 11.5 & 4 \\
\hline 12 & 5 \\
\hline
\end{tabular}

The above table quantifies the risk for every Respondent of this region. Here the highest hazard score is 12 got by five families, illustrating that those families are in the most precarious position in terms of the region's different climatic disasters. The table also elucidates that the hazard score of forty-nine families is between 10 to 11.5 , more than $25 \%$ of the total respondents. Forty-two families lie between $8.5-9.5,43 \%$ of the total Respondent. The rest of the four respondents' score lies between $5.5-8,3.56 \%$ of the total respondents.

\section{Conclusion}


Bangladesh is one of the vulnerable countries due to climate change. The position and Rapid climate change, cyclone, tidal surge, excessive rainfall made the study area prone, and the level of exposure of Mongla will increase over time. The study comprehensively specified a few factors: socioeconomic status, livelihood options, climate change-induced adverse impacts, hazards, women empowerment, advocacy, water issues, and the health of the populations and households. Establishing a model for the future study is the pith part of this study, and findings denoted challenges waiting in the future for the study area. This paper determined that many villagers cannot access safe drinking water during the summer. Poverty impediment the development of the study area; according to the findings, $60-70 \%$ of people live below the poverty line. The study area has found consequences of climate change such as lack of freshwater, salinity into the soil, and food scarcity. Negative factors like the area are becoming warmer and dryer, supported by the maximum population in the study area. This paper analyzed the condition and created a new avenue for the policymaker to generate sustainable policy. Alignment of adaptability and mitigation can address the current climate vulnerability of the Mongla. Separate treatment of adaptability and mitigation will not provide a long-term sustainable solution. Still, it is suggested that policymakers establish a long-term national action plan that can overcome the potential risks of thousands of families in the area. On-headed family income is inadequate to eradicate poverty; diversification of income and involvement of women is highly recommended. Identify the critical constraints of agriculture and implement advanced methods such as seed that provide high yield in an adverse environment. Sustainable use of rainwater can be fruitful to address the lack of freshwater. This paper strengthens the argument about climate change and enhances the value of adaptation and mitigation.

\section{Declarations}

\section{Acknowledgements:}

We thank the respondents who actively participated in the survey and gave valuable opinions to conduct this research. We are also grateful to the authorities who guided us.

\section{Conflict of interests}

The authors declare that they have no known competing financial or personal interests or personal relationships that could have appeared to influence the work reported in this paper.

\section{References}

Abedin, M. A., Collins, A. E., Habiba, U., \& Shaw, R. (2019). Climate Change, Water Scarcity, and Health Adaptation in Southwestern Coastal Bangladesh. International Journal of Disaster Risk Science, 10(1), 28-42. https://doi.org/10.1007/s13753-018-0211-8

Agrawala, S., Ota, T., Ahmed, A. U., Smith, J., A., \& van Alast, M. (2003). Development and Climate Change in Bangladesh: focus on coastal flooding and the Sundarbans. Organisation for Economic Co-Operation 
and Development-OECD, 1-70. http://www.pisa.oecd.org/dataoecd/46/55/21055658.pdf

Ahmed, I., Hossain, R., Tasnim, T., Mannan, S., \& Huq, D. S. (2019). Research Report on Understanding Climate Change Vulnerability in Two Coastal Villages in Bangladesh and Exploring Options for Resilience.

Ahmed, P., \& Biswas, R. (2012). Disaster Risk Reduction Measures in Bangladesh. World Construction Conference 2012 - Global Challenges in Construction Industry, June, 209-220. http://eprints.hud.ac.uk/

Ali, S. S. M. M. R. N. R. C. (2012). Bangladesh: A Sustainable and Disaster Resilient Future.

Amoako Johnson, F., Hutton, C. W., Hornby, D., Lázár, A. N., \& Mukhopadhyay, A. (2016). Is shrimp farming a successful adaptation to salinity intrusion? A geospatial associative analysis of poverty in the populous Ganges-Brahmaputra-Meghna Delta of Bangladesh. Sustainability Science, 11(3), 423-439. https://doi.org/10.1007/s11625-016-0356-6

Balakrishnan, R. (2005). Rural women and food security in Asia and the Pacific: Prospects and paradoxes. Rap Publication. http://www.fao.org/3/af348e/af348e07.htm

Baten, A., Arcos González, P., \& Delgado, R. C. (2018). Natural Disasters and Management Systems of Bangladesh from 1972 to 2017: Special Focus on Flood. OmniScience: A Multi-Disciplinary Journal, 8(3), 35-47. www.stmjournals.com

Benneyworth, L., Gilligan, J., Ayers, J. C., Goodbred, S., George, G., Carrico, A., Karim, M. R., Akter, F., Fry, D., Donato, K., \& Piya, B. (2016). Drinking water insecurity: water quality and access in coastal south-western Bangladesh. International Journal of Environmental Health Research, 26(5-6), 508-524.

https://doi.org/10.1080/09603123.2016.1194383

Bhowmick, B., Uddin, Z., \& Rahman, S. (2017). Salinity Changes in South West Bangladesh and Its Impact on Rural Livelihoods. Bangladesh Journal of Veterinary Medicine, 14(2), 251-255.

https://doi.org/10.3329/bjvm.v14i2.31405

Davidson, N., Delany, S., \& Seddon, M. (2001). Biodiversity Impacts of Large Dams: Waterbirds.

September. https://www.researchgate.net/publication/255643683_Biodiversity_Impacts_of_Large_Dams

Dewald, van N. (2011). Introduction To Disaster Risk Reduction. Usaid, August, 59.

Dewan, T. H. (2015). Societal impacts and vulnerability to floods in Bangladesh and Nepal. Weather and Climate Extremes, 7, 36-42. https://doi.org/10.1016/j.wace.2014.11.001

Hasan, M. K., Shahriar, A., \& Jim, K. U. (2019). Water pollution in Bangladesh and its impact on public health. Heliyon, 5(8), e02145. https://doi.org/10.1016/j.heliyon.2019.e02145

Hasnat, G. N. T., Kabir, M. A., \& Hossain, M. A. (2018). Major Environmental Issues and Problems of South Asia, Particularly Bangladesh. In Handbook of Environmental Materials Management (pp. 1-40). 
Hossain, M. A. R., \& Hasan, M. R. (2017). An assessment of impacts from shrimp aquaculture in Bangladesh and prospects for improvement. In FAO Fisheries and Aquaculture Technical Paper No. 618 (Vol. 160, Issue September).

Hossain, M. S., Uddin, M. J., \& Fakhruddin, A. N. M. (2013). Impacts of shrimp farming on the coastal environment of Bangladesh and approach for management. In Reviews in Environmental Science and Biotechnology (Vol. 12, Issue 3, pp. 313-332). Springer. https://doi.org/10.1007/s11157-013-9311-5

ICSU. (2005). ICSU Scoping Group on Natural and Human-induced Environmental Hazards. ICSU 28th General Assembly.

Islam, MA, Parvin, S., \& Farukh, M. (2017). Impacts of riverbank erosion hazards in the Brahmaputra floodplain areas of Mymensingh in Bangladesh. Progressive Agriculture, 28(2), 73-83. https://doi.org/10.3329/pa.v28i2.33467

Islam, MS, Sultana, S., Saifunnahar, M., \& Miah, M. (2015). Adaptation of Char Livelihood in Flood and River Erosion Areas through Indigenous Practice: A Study on Bhuapur Riverine Area in Tangail. Journal of Environmental Science and Natural Resources, 7(1), 13-19. https://doi.org/10.3329/jesnr.v7i1.22138

Jerin, M., Mondol, S., Sarker, B., Rimi, R., \& Aktar, S. (2017). Impacts of Brick Fields on Environment and Social Economy at Bagatipara, Natore, Bangladesh. Journal of Environmental Science and Natural Resources, 9(2), 31-34. https://doi.org/10.3329/jesnr.v9i2.32148

Karim, N. (1995). Disasters in Bangladesh. Natural Hazards, 11(3), 247-258. https://doi.org/10.1007/BF00613409

Khatun, M. R., Gossami, G. C., Akter, S., Barman, M. C., Paul, G. C., History, L. I. F. E., \& Aila, O. F. (2017). Impact of the tropical cyclone AlLA along the coast of Bangladesh. International Journal of Scientific \& Engineering Research, 8(12), 1592-1599.

Masum, J. H. (2020). Climatic Hazards in Bangladesh-A Literature Review Jahangir Hasan Masum. November 2019.

Md. Asaduzzaman, M., Kabir, R., \& Radović-Marković, M. (2015). Gender Inequality in Bangladesh. Journal of Women's Entrepreneurship and Education, 2(3-4), 54-64.

Md. Esraz-Ul-ZannatMaureen Fordham, Ahmed, Bayes, M. S. (2017). Social Vulnerability to Cyclone Disasters in Khulna District in Southwest Social Vulnerability to Cyclone Disasters in Khulna District in Southwest Bangladesh Report Prepared by Institute for Risk and Disaster Reduction, University College London (UCL ). December. https://doi.org/10.13140/RG.2.2.36136.11528 
Profile, S. E. E., \& Profile, S. E. E. (2016). Impacts of Climate change on natural resource bases and peoples livelihood of south western coastal region of Bangladesh and Adaptation strategy in agricultural sector By M Yusuf Ali and M Emdad Hossain CCAFS, WorldFish, South Asia and Bangladesh Office. September 2017. https://doi.org/10.13140/RG.2.2.21438.59202

Rahman, M. H., Rahman, M. S., \& Rahman, M. M. (2017). Disasters in Bangladesh: Mitigation and Management. Barisal University Journal Part 1, 4 (1): 139-163 (2017), 4(1), 139-163.

Sarwar, M. G. M. (2005). Impacts of Sea Level Rise on the Coastal Zone of Bangladesh. Response, 45.

Sudmeier-rieux, K., Masundire, H., Rizvi, A., \& Rietbergen, S. (2006). Ecosystems, livelihoods and disasters:an integrated approach to disaster risk management. In Ecosystems, livelihoods and disasters :an integrated approach to disaster risk management (Issue 4). https://doi.org/10.2305/iucn.ch.2006.cem.4.en

Usman, A. R., Olorunfemi, F. ., Ayotawo, G. ., Tunde, A. ., \& Usman, B. . (2013). Disaster Risk Management and Social Impact Assessment: Understanding Preparedness, Response and Recovery in Community Projects. In Environmental Change and Sustainability. InTech. https://doi.org/10.5772/55736

Yasmin, T. (2020). Overview of laws, policies and practices on gender-based violence and harassment in the world of work in Bangladesh.

\section{Figures}




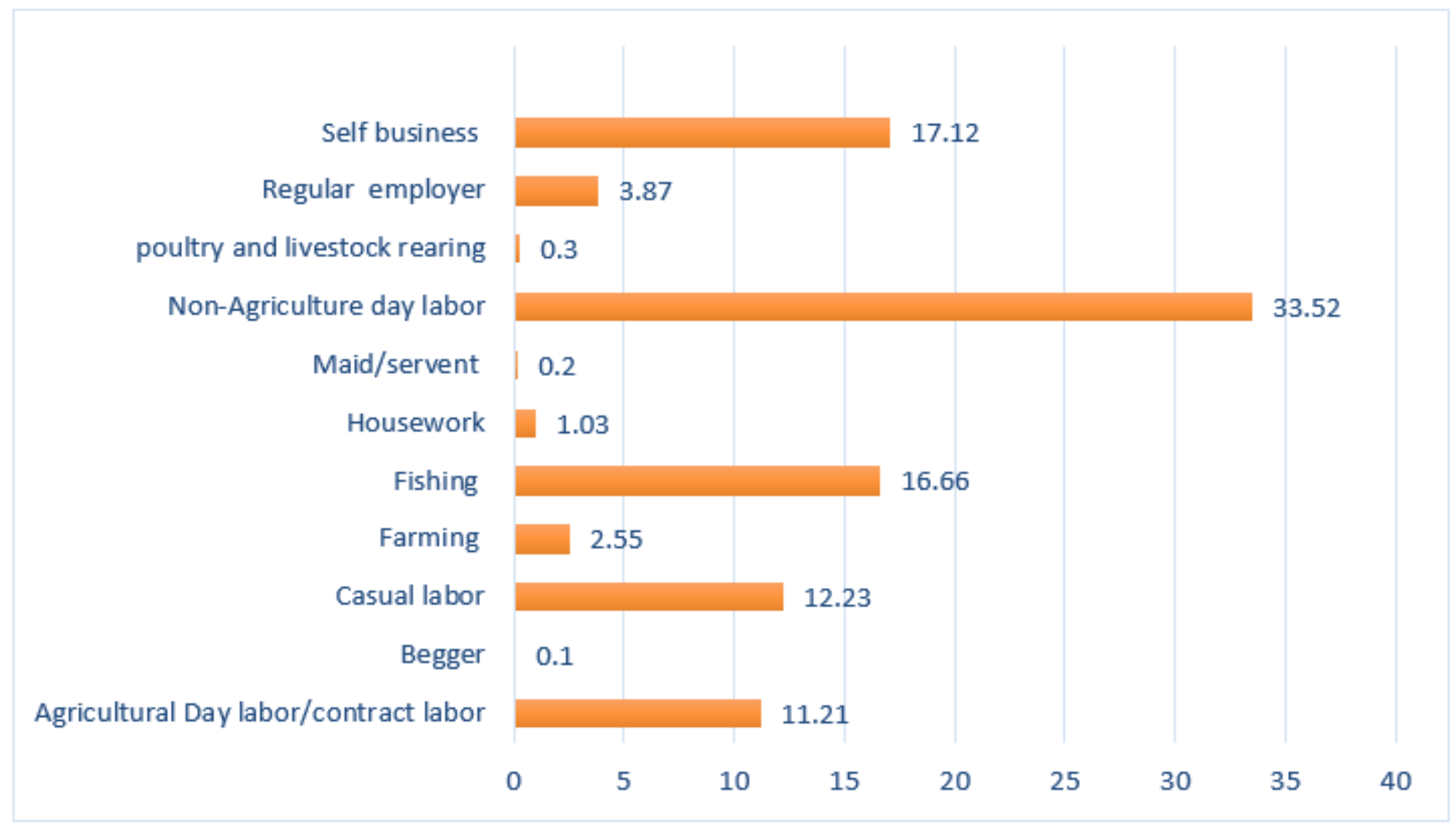

\section{Figure 1}

Occupation of Respondent Families (\%)

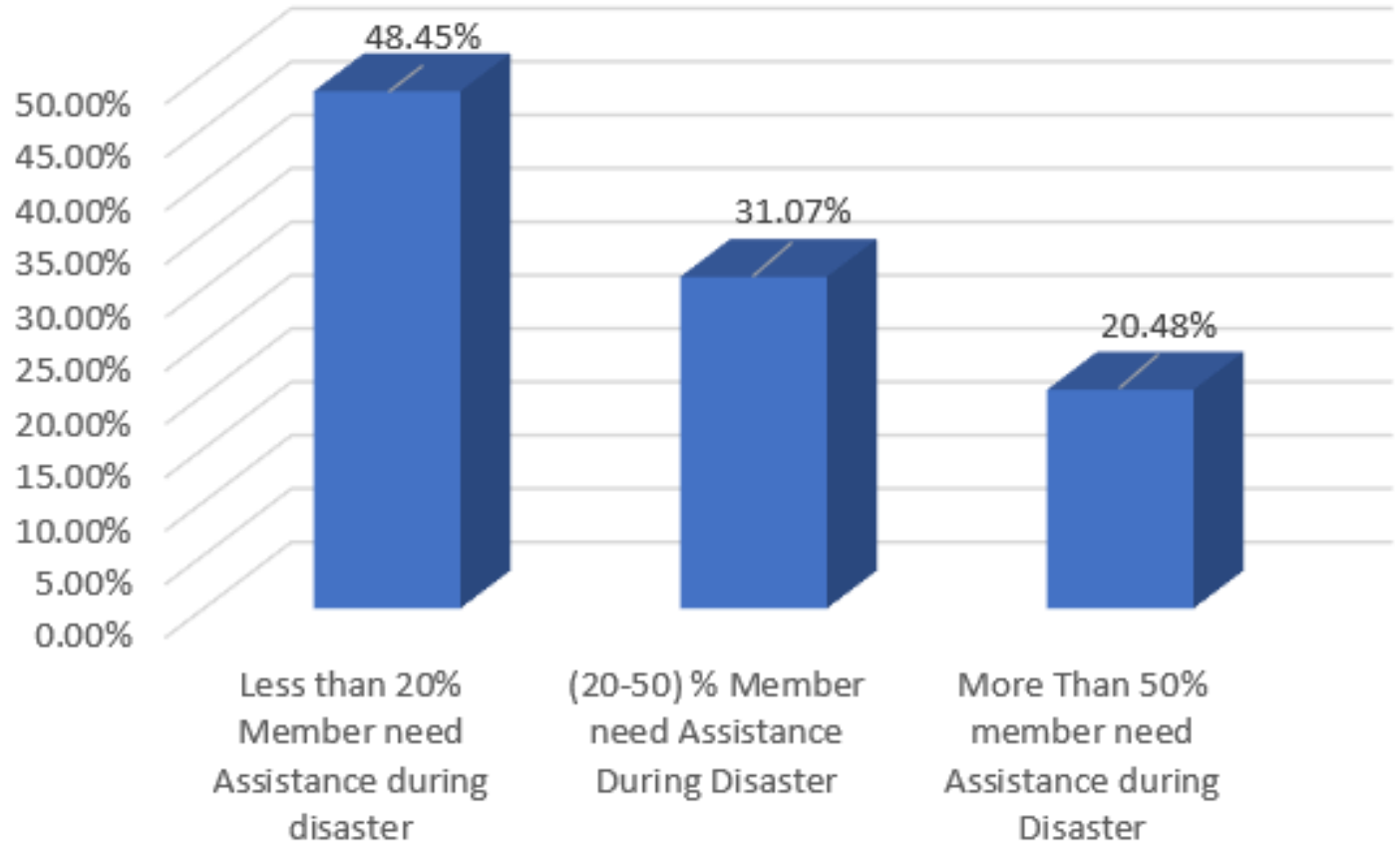

Figure 2 
Assistance during Disaster (\%)

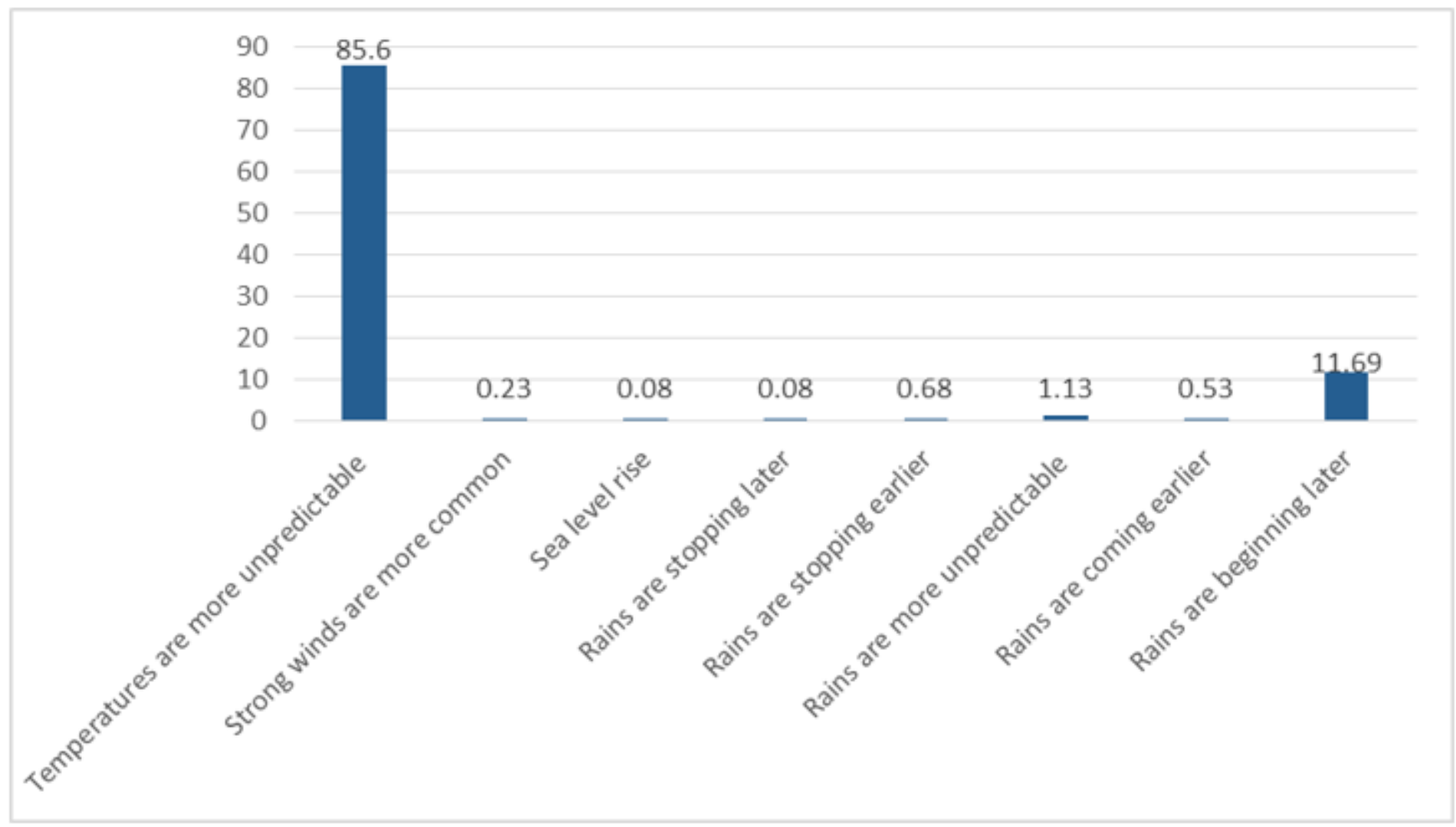

Figure 3

Knowledge of Locals about Climate Change impact (\%) 
60

\subsection{6}

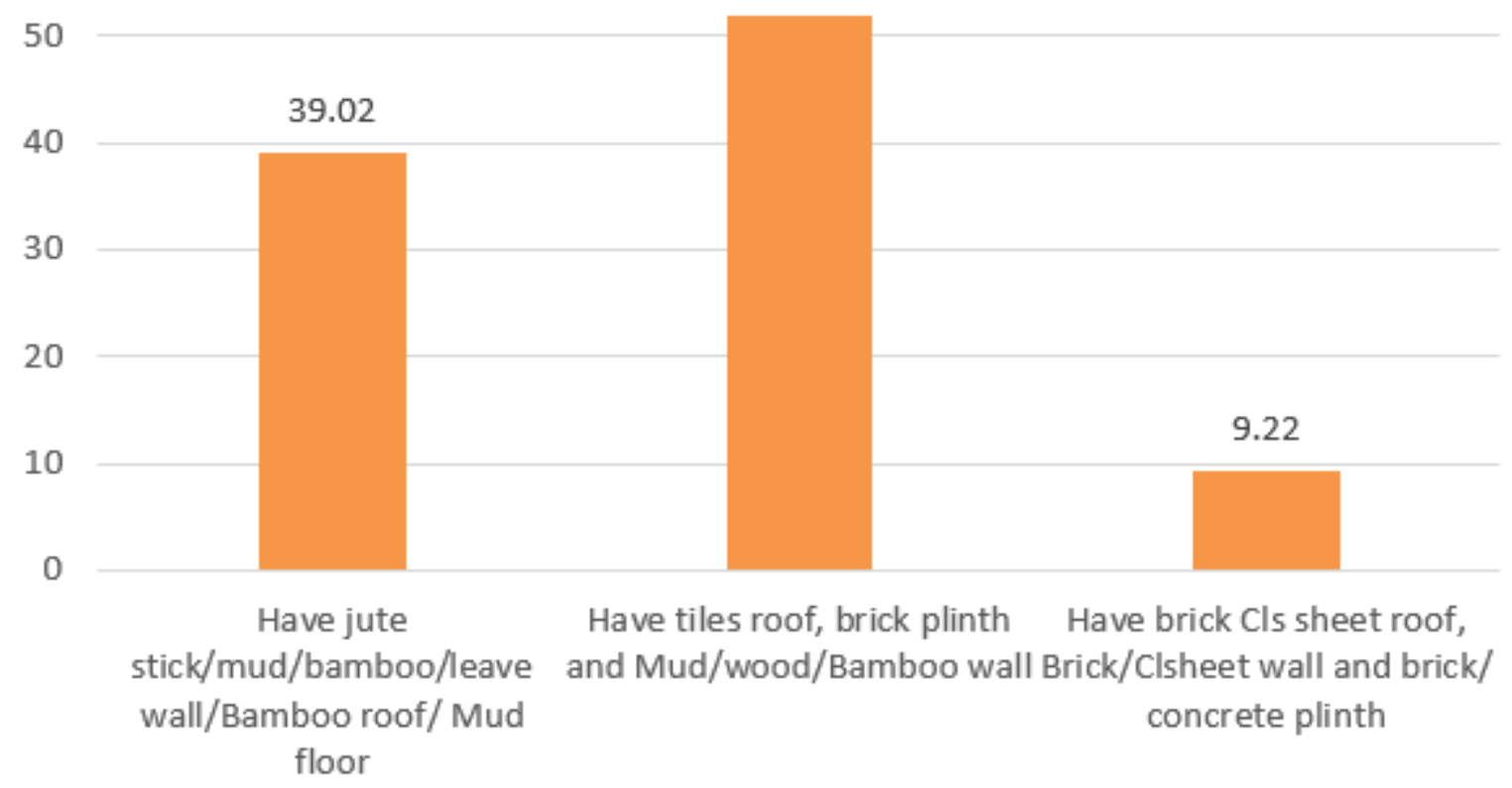

\section{Figure 4}

Status on Building Asset (\%)

Use PSF pipewater \& are available within 58 months

Use RWHS, Tube wells with high plinth \& are available $>4$ months

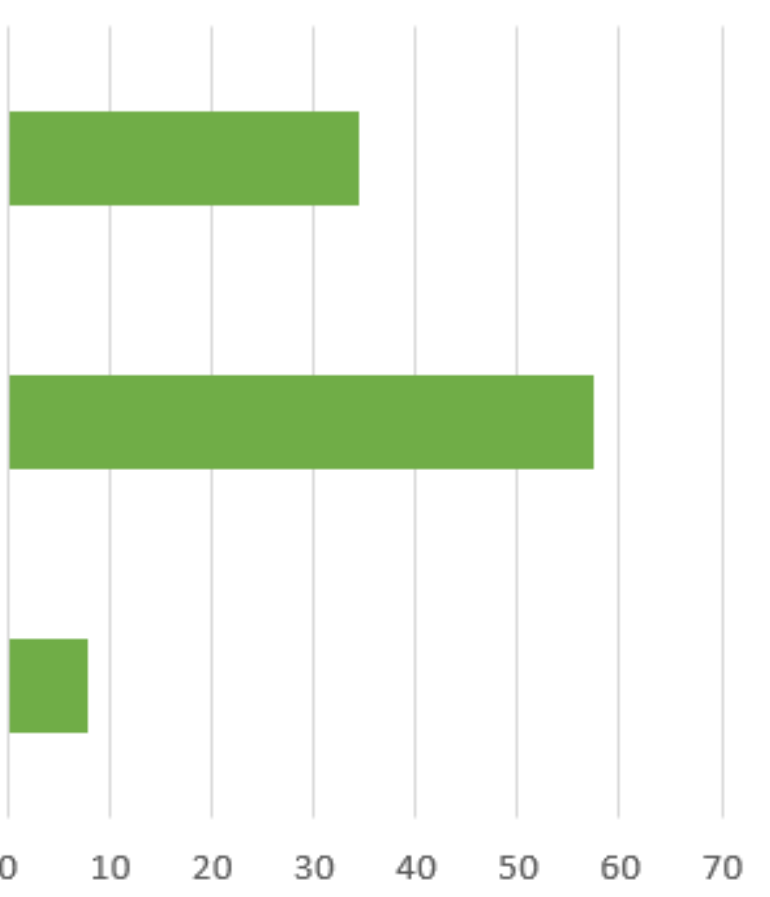

\section{Figure 5}

Status of Drinking water source (\%) 
Figure 6

Status of Income (\%)

\section{Figure 7}

Status of Irrigation Practice (\%)

\section{Figure 8}

Status of Land Exposed to Risk (\%)

\section{Figure 9}

Recent faced Disaster (\%)

\section{Figure 10}

Community Perception on Reducing the Impact of Future Disaster (\%)

\section{Figure 11}

Community Perception on Climate Change (\%) 